\title{
PENERAPAN LEMBAR KERJA EKSPERIMEN UNTUK MELATIH KETERAMPILAN PROSES SAINS SISWA SMA
}

\author{
Hikmawati $^{1 *}$, Kusmiyati ${ }^{2}$, Sutrio ${ }^{1}$ \\ Program Studi Pendidikan Fisika, Universitas Mataram \\ Program Studi Pendidikan Biologi, Universitas Mataram \\ *Email: hikmawati@unram.ac.id
}

DOI: http://dx.doi.org/10.29303/jpft.v5i1.1062

\begin{abstract}
Limited trial studies have been carried out on the application of Experimental Worksheets to train High School Student Science Process Skills (SPS). The limited trial subjects of the application of worksheets were students of class XI IPA-1 at SMAN 1 Kediri in the 2017/2018 Academic Year with a total of 21 people. The number of worksheets tested in physics learning material Temperature, Heat, and Heat Transfer are a number of 6 pieces consisting of worksheets for experiments Putting test marks on Thermometers, Substance Expansion, Change in Objects, Black Principle, Heat Transfer, and Heat Equation. Worksheets in this study aimed to trains students to improve the ability to formulate problems, make hypotheses, conduct experiments, and interpret information. In implementing these worksheets, the teacher uses the experimental method in learning activities with 4 meetings. The average SPS score obtained by students for each worksheet is 80 with good criteria. Thus, worksheets can be an alternative for physics teachers in training SPS students in high school.
\end{abstract}

Keywords: Experiment, Worksheets, Science Process Skills.

\section{PENDAHULUAN}

Menurut Ostlund (1992) dan Raj \& Devi (2014), keterampilan proses sains (KPS) didefinisikan sebagai keterampilan yang mencerminkan perilaku para ilmuwan. Keterampilan tersebut merupakan keterampilan yang memfasilitasi partisipasi siswa untuk aktif dalam kegiatan pembelajaran sehingga siswa dapat mengembangkan rasa tanggung jawab dalam pembelajaran, dan juga melatih siswa memperoleh cara dan metode penelitian, yaitu, siswa berperilaku seperti seorang ilmuwan. Harlen (1999) dan Zeidan \& Jayosi (2015) menyebutkan bahwa KPS dikenal sebagai keterampilan prosedural, eksperimental dan kemampuan penyelidikan ilmiah.

Bybee \& DeBoer (1993) dan Tilakaratne \& Ekanayake (2017) berpendapat bahwa keterampilan metode ilmiah sangat penting untuk mengajarkan cara mencapai kesimpulan berdasarkan pengetahuan yang ada. Istilah yang berbeda telah digunakan untuk menggambarkan keterampilan ini seperti metode ilmiah, pemikiran ilmiah dan pemikiran kritis, dan lain-lain. Namun, selama dua dekade terakhir, frase "keterampilan proses sains" telah menjadi lebih umum digunakan.

Harlen (1999) dan Karamustafaoğlu (2011) menyatakan bahwa selama beberapa dekade terakhir, pendidik sains telah memusatkan perhatian pada proses sains dasar dan terpadu. KPS sangat penting untuk pembelajaran yang bermakna; karena pembelajaran terus berlanjut sepanjang hidup, dan siswa perlu menemukan, menafsirkan, dan menilai bukti dalam berbagai kondisi yang mereka hadapi. Oleh karena itu, sangat penting bagi masa depan siswa untuk diberikan KPS di lembaga pendidikan. Foulds \& Rowe (1996) menyatakan bahwa pembelajaran sains dan pengembangan KPS adalah kegiatan yang terintegrasi.

Aydoğdu, Erkol \& Erten (2014) mengatakan bahwa kemampuan untuk menggunakan KPS untuk masalah seharihari adalah penting bagi siswa yang hidup dalam masyarakat yang berkembang pesat. Siswa dengan keterampilan ini memiliki 
kemampuan untuk memberikan kontribusi besar bagi peningkatan masyarakat. Sebagian besar siswa mengembangkan keterampilan ini melalui pendidikan formal dan interaksi dengan guru mereka. Oleh karena itu, guru memainkan peran penting dalam pengembangan KPS.

Salah satu upaya yang dapat dilakukan untuk mengembangkan KPS siswa yaitu dengan menerapkan Lembar Kerja Siswa (LKS) berupa Lembar Kerja Eksperimen (LKE). Menurut Trianto (2008), LKS adalah panduan siswa yang digunakan untuk melakukan kegiatan penyelidikan atau pemecahan masalah. Berdasarkan metodenya ada 2 LKS yaitu eksperimen dan non eksperimen. LKS eksperimen adalah LKS yang digunakan pedoman untuk melaksanakan eksperimen dan dapat memuat semua jenis keterampilan proses, sedangkan LKS non eksperimen adalah LKS yang dijadikan pedoman untuk memahami konsep atau prinsip tanpa melakukan eksperimen dan hanya memuat ketrampilan proses tertentu, misalnya mentranslasikan, meyimpulkan, menjelaskan, menafsirkan atau menginterpretasikan, dan meramalkan. Penyajiannya dilakukan melalui diskusi, tanya jawab, dan demonstrasi. Kelebihan LKS tersebut dapat di lihat pada Tabel 1.

Tabel 1. Kelebihan LKS

\begin{tabular}{|c|c|}
\hline LKS Eksperimen & $\begin{array}{l}\text { LKS Non } \\
\text { Eksperimen }\end{array}$ \\
\hline $\begin{array}{l}\text { - Melibatkan banyak } \\
\text { indra }\end{array}$ & $\begin{array}{l}\text { - Waktu lebih } \\
\text { efisien }\end{array}$ \\
\hline $\begin{array}{l}\text { Melatih ketrampilan } \\
\text { proses }\end{array}$ & $\begin{array}{l}\text { Relatif murah } \\
\text { dan hemat } \\
\text { tenaga }\end{array}$ \\
\hline $\begin{array}{l}\text { Menanamkan } \\
\text { disiplin dan } \\
\text { tanggungjawab }\end{array}$ & $\begin{array}{l}\text { Target } \\
\text { kurikulum dan } \\
\text { mudah dicapai }\end{array}$ \\
\hline $\begin{array}{l}\text { Menantang siswa } \\
\text { untuk menemukan } \\
\text { hal yang baru }\end{array}$ & $\begin{array}{l}\text { Organisasi dan } \\
\text { perencanaan } \\
\text { lebih terkendali }\end{array}$ \\
\hline $\begin{array}{l}\text { Menggugah ide } \\
\text { orisinal siswa }\end{array}$ & $\begin{array}{l}\text { - Lebih mudah } \\
\text { penggunaaanya }\end{array}$ \\
\hline
\end{tabular}

Tujuan penelitian ini adalah menerapkan LKE untuk melatih KPS siswa di tingkat SMA.

\section{METODE PENELITIAN}

Kegiatan ujicoba terbatas penerapan LKE untuk melatih KPS siswa dalam penelitian ini merupakan salah satu tahapan dalam tahap Develop. Tahap Develop merupakan tahapan yang terdapat dalam model pengembangan perangkat pembelajaran, yakni model four-D (Define, Design, Develop, Disseminate). Model ini disarankan oleh Thiagarajan, Semmel, dan Semmel dalam Trianto (2008) dan Ibrahim (2003).

Jumlah LKE yang diujicoba dalam penelitian ini berjumlah 6 buah dengan materi pembelajaran yang diajarkan yaitu Suhu, Kalor, dan Perpindahan Kalor. LKE tersebut terdiri atas LKE untuk percobaan Membubuhkan tanda uji pada Termometer, Pemuaian Zat, Perubahan Wujud Benda, Asas Black, Perpindahan Kalor, dan Persamaan Kalor. LKE dalam penelitian ini merupakan lembar kerja yang melatih siswa untuk meningkatkan kemampuan merumuskan masalah, membuat hipotesis, melakukan eksperimen, dan menafsirkan informasi.

Kegiatan ujicoba terbatas penerapan LKE untuk melatih KPS siswa dilakukan di SMAN 1 Kediri Tahun Ajaran 2017/2018. Subjek ujicoba terbatas penerapan LKE adalah siswa kelas XI IPA-1 sejumlah 21 orang. Dalam penerapan LKE ini guru model menggunakan metode eksperimen dalam kegiatan pembelajaran dengan jumlah pertemuan sebanyak 4 kali.

Penentuan nilai KPS siswa untuk setiap LKE dalam penelitian ini menggunakan standar mutlak (absolut) skala lima sebagaimana dijelaskan Sahidu (2013) dapat dilihat pada Tabel 2. 
Tabel 2. Kriteria Nilai KPS

\begin{tabular}{lll}
\hline Nilai KPS & $\begin{array}{l}\text { Skor } \\
\text { Standar }\end{array}$ & Kriteria \\
\hline $90-100$ & A & Sangat baik \\
\hline $80-89$ & B & Baik \\
\hline $65-79$ & C & Cukup \\
\hline $55-64$ & D & Kurang \\
\hline $0-54$ & E & Sangat kurang \\
\hline
\end{tabular}

\section{HASIL DAN PEMBAHASAN}

Nilai rata-rata KPS tiap siswa adalah sebesar 80, dengan nilai terendah 71 dan nilai tertinggi sebesar 91. Dalam kegiatan ujicoba terbatas ini, guru model membagi kelompok ke dalam 4 kelompok belajar siswa. Dengan bimbingan dari guru model, semua anggota kelompok saling bekerjasama untuk menyelesaikan setiap tugas yang terdapat pada LKE. Data nilai rata-rata KPS tiap siswa dapat dilihat pada Gambar 1.

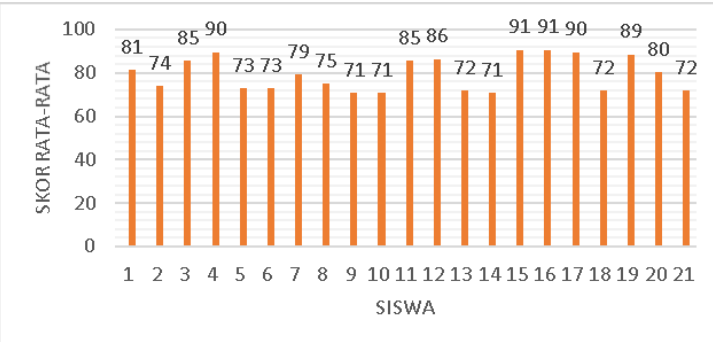

Gambar 1. Nilai rata-rata KPS tiap siswa

Kriteria nilai KPS siswa untuk setiap LKE mengalami peningkatan, yaitu dari kriteria Cukup pada LKE 1 naik menjadi kriteria Baik pada LKE 6. Nilai KPS siswa pada LKE 1 untuk percobaan Membubuhkan tanda uji pada Termometer adalah sebesar 70 (Skor C), LKE 2 untuk percobaan Pemuaian Zat sebesar 72 (Skor C), LKE 3 untuk percobaan Perubahan Wujud Benda sebesar 81 (Skor B), LKE 4 untuk percobaan Asas Black sebesar 81 (Skor B), LKE 5 untuk percobaan Perpindahan Kalor sebesar 87 (Skor B), dan LKE 6 untuk percobaan Persamaan Kalor sebesar 87 (Skor B). Penggunaan LKE dalam pembelajaran fisika menggunakan metode eksperimen dalam penelitian ini telah mampu meningkatkan KPS siswa. Data kriteria nilai KPS siswa untuk setiap LKE dapat dilihat pada Tabel 3.

Tabel 3. Kriteria nilai KPS untuk tiap LKE

\begin{tabular}{llll}
\hline LKE & Nilai KPS & Skor & Kriteria \\
\hline 1 & 70 & C & Cukup \\
\hline 2 & 72 & C & Cukup \\
\hline 3 & 81 & B & Baik \\
\hline 4 & 81 & B & Baik \\
\hline 5 & 87 & B & Baik \\
\hline 6 & 87 & B & Baik \\
\hline
\end{tabular}

Komponen KPS siswa yang dilatih melalui penerapan LKE dalam penelitian adalah kemampuan merumuskan masalah, membuat hipotesis, melakukan eksperimen, dan menafsirkan informasi. Masing-masing komponen KPS memiliki beberapa indikator seperti dijelaskan Semiawan et al. (1987), Indrawati (2000), dan Trianto (2008) sebagai berikut. Kemampuan merumuskan masalah dapat dilihat dari beberapa indikator yaitu: Mengajukan sebanyak mungkin pertanyaan; Mengidentifikasi pertanyaan yang dapat dijawab dengan penemuan ilmiah; Mengubah pertanyaan menjadi bentuk yang dapat dijawab dengan percobaan; Merumuskan pertanyaan berlatang belakang hipotesis (jawab dapat dibuktikan).

Kemampuan membuat hipotesis dapat dilihat dari beberapa indikator yaitu: Mencoba menjelaskan pengamatan dalam terminologi konsep dan prinsip; Menyadari fakta bahwa terdapat terdapat beberapa kemungkinan untuk menjelaskan suatu gejala; Menggunakan penjelasan untuk membuat prediksi dari sesuai yang dapat diamati atau dibuktikan. Kemampuan melakukan eksperimen dapat dilihat dari beberapa indikator yaitu: Merumuskan masalah; Menemukenali variabel kontrol; Membandingkan variabel bebas dan variabel terikat; Merancang cara melakukan pengamatan untuk memecahkan masalah; Memilih alat dan bahan yang sesuai; 
Menentukan langkah-langkah percobaan; Menentukan cara yang tepat untuk mengumpulkan data.

Kemampuan menafsirkan informasi dapat dilihat dari beberapa indikator yaitu: Menarik kesimpulan; Menggunakan kunci atau klasifikasi; Menyadari bahwa kesimpulan bersifat tentatif; Menggeneralisasi; Membuat dan mencari pembenaran dari kesimpulan sementara; Membuat prediksi berdasarkan pola atau patokan tertentu. Kemampuan menafsirkan informasi atau keterampilan interpretasi data biasanya diawali dengan pengumpulan data, analisis data, dan mendeskripsikan data. Mendeskripsikan data artinya menyajikan data dalam bentuk yang mudah dipahami misalnya bentuk tabel, grafik dengan angkaangka yang sudah dirata-ratakan. Data yang sudah dianalisis baru diinterpretasikan menjadi suatu kesimpulan atau dalam bentuk pernyataan. Seluruh indikator tersebut dapat ditingkatkan melalui kegiatan eksperimen. Kegiatan eksperimen dapat meningkatkan keterampilan proses sains dan kemampuan berpikir kreatif peserta didik (Gunawan, 2017; Gunawan et al. 2018).

Untuk dapat melatih KPS siswa maka diharapkan guru menerapkan pembelajaran yang berpusat pada aktivitas siswa, seperti penggunaan metode eksperimen dengan LKE dalam penelitian ini. KPS siswa dapat dilatih mulai dari jenjang pendidikan dasar hingga perguruan tinggi. Beberapa penelitian tentang keterampilan proses sains yang berpusat pada aktivitas siswa adalah sebagai berikut. Pembelajaran berbasis masalah memberikan pengaruh yang lebih baik dan signifikan terhadap keterampilan proses sains siswa kelas V SD (Handika \& Wangid, 2013), penerapan pembelajaran inkuiri terbimbing memberikan pengaruh yang signifikan terhadap ketrampilan proses sains siswa kelas VIII SMP (Ambarsari, dkk., 2013), penerapan model pembelajaran inkuiri dapat meningkatkan keterampilan proses sains siswa kelas XI SMA (Rahmasiwi, dkk., 2015), terjadi peningkatan keterampilan proses sains mahasiswa melalui penerapan model pembelajaran kontekstual pada mahasiswa semester I materi dinamika (Marnita, 2013).

Keterampilan proses sains dapat dikembangkan melalui kegiatan laboratorium. Kegiatan laboratorium memberikan peluang dalam mengembangkan indikator-indikator seperti melakukan pengamatan sampai membuat kesimpulan. Tidak terbatas pada laboratorium riil saja, bahkan penerapan laboratorium virtual dapat melatih keterampilan proses sains siswa (Gunawan et al. 2019).

Perkembangan keterampilan proses sains siswa tidak bisa dilepas begitu saja. Artinya, siswa membutuhkan penopang dalam setiap prosesnya. Hal ini ditunjukkan pada beberapa penelitian yang menunjukkan perkembangan keterampilan proses sains sebagian besar disandingkan dengan model pembelajaran lain yang didalamnya terdapat panduan atau bimbingan dari guru (Tuada et al. 2017; Azizirrahim et al. 2017; Juraini et al. 2017). Hal ini menunjukkan bahwa LKE sangat diperlukan sebagai panduan siswa dalam mengembangkan keterampilan proses sains mereka.

\section{PENUTUP}

Berdasarkan hasil penelitian dan pembahasan yang telah dipaparkan, maka dapat disimpulkan bahwa: penerapan LKE untuk materi pembelajaran Suhu, Kalor, dan Perpindahan Kalor dengan metode eksperimen dapat meningkatkan KPS siswa di SMA. KPS siswa meningkat dari kriteria Cukup dengan nilai 70 pada LKE 1 naik menjadi kriteria Baik dengan nilai 87 pada LKE 6. 


\section{REFERENSI}

Ambarsari, W., Santosa, S., Maridi. 2013. Penerapan Pembelajaran Inkuiri Terbimbing Terhadap Keterampilan Proses Sains Dasar Pada Pelajaran Biologi Siswa Kelas VIII SMP Negeri 7 Surakarta. Pendidikan Biologi 5(1), 81-95.

Aydoğdu, B., Erkol, M \& Erten, N. 2014. The investigation of science process skills of elementary school teachers in terms of some variables: Perspectives from Turkey. Asia-Pacific Forum on Science Learning and Teaching, 15(1), 8, p.2.

Azizirrahim, E., Sutrio, S., \& Gunawan, G. 2017. Penerapan Pendekatan Keterampilan Proses Sains dalam Model Pembelajaran Guided Discovery untuk Meningkatkan Hasil Belajar IPA Fisika pada Siswa Kelas VIIA SMPN 8 Mataram Tahun Ajaran 2015/2016. Jurnal Pendidikan Fisika dan Teknologi, 1(4), 272-275.

Bybee, R. W., \& DeBoer, G. E. 1993. Research on the goals for the science curriculum. In Gabel, D.L. (Eds.), Handbook of Research on Science Teaching and Learning (Pp. 357-387). New York: National Science Teachers Association.

Foulds, W., \& Rowe, J. 1996. The enhancement of science process skills in primary teacher education students. Australian Journal of Teacher Education, 21(1): 16-23.

Gunawan, G., Harjono, A., Hermansyah, H., \& Herayanti, L. 2019. Guided Inquiry Model Through Virtual Laboratory to Enhance Students' Science Process Skills on Heat Concept. Jurnal Cakrawala Pendidikan, 38(2), 259268.

Gunawan, G., Nisrina, N., Suranti, N. M. Y., Herayanti, L., \& Rahmatiah, R. (2018, November). Virtual Laboratory to Improve Students' Conceptual Understanding in Physics Learning. In
Journal of Physics: Conference Series 1108(1), p. 012049.

Gunawn, G. 2017. Keterampilan Berpikir dalam Pembelajaran Sains. Mataram: Arga Puji Press.

Handika, I., Wangid, M., N. 2013. Pengaruh Pembelajaran Berbasis Masalah Terhadap Penguasaan Konsep Dan Keterampilan Proses Sains Siswa Kelas V. Jurnal Prima Edukasia, Volume I, Nomor 1, 85-93.

Harlen, W. 1999. Purposes and procedures for assessing science process skills. Assessment in Education: Principles, Policy \& Practice, 6(1), 129-144.

Ibrahim, M. 2003. Pengembangan Perangkat Pembelajaran. Jakarta: Dirjen Dikdasmen Depdiknas.

Indrawati. 2000. Keterampilan Proses Sains/IPA. Bandung: PPPGIPA.

Juraini, J., Taufik, M., \& Gunada, I. W. 2017. Pengaruh Model Pembelajaran Kooperatif Tipe STAD (Student Team Achievement Division) dengan Metode Eksperimen Terhadap Keterampilan Proses Sains dan Hasil Belajar Fisika pada Siswa SMA Negeri 1 Labuapi Tahun Pelajaran 2015/2016. Jurnal Pendidikan Fisika dan Teknologi, 2(2), 80-85.

Karamustafaoğlu, S. 2011. Improving the Science Process Skills Ability of Science Student Teachers Using I Diagrams. Eurasian Journal of Physics and Chemistry Education. 3(1): 26-38.

Marnita. 2013. Peningkatan Keterampilan Proses Sains Melalui Pembelajaran Kontekstual Pada Mahasiswa Semester I Materi Dinamika. Jurnal Pendidikan Fisika Indonesia, 9: 4352.

Ostlund, K., L. 1992. Science Process Skills: Assessing Hands-On Student Performance. New York: AddisonWesley.

Rahmasiwi, A., Santosari, S., Sari, D. P. 2015. Peningkatan Keterampilan 
